\title{
Penyuluhan Masyarakat Mojogede Pada Pemanfaatan Minuman Fungsional Kombinasi Jahe dan Serai
}

\author{
Janatun Na'imah, Heru Baskoro, Anindi Lupita Nasyanka* \\ Program Studi DIII Farmasi Fakultas Kesehatan, Universitas Muhammadiyah Gresik, Gresik, Indonesia
}

Article history

Received: 29-06-2020

Revised: 07-07-2020

Accepted: 17-07-2020

*Corresponding Author: Anindi Lupita Nasyanka, Universitas Muhammadiyah Gresik, Gresik, Indonesia;

Email: anindilupita@umg.ac.id janatunnaimah@umg.ac.id

\begin{abstract}
Coronavirus Disease 2019 (Covid-19) is a new type of disease that has never been identified before in humans. The virus that causes Covid-19 is called Sars-CoV-2. This research was conducted to educate the public about the use of ginger and lemongrass functional drinks to improve immunity. The method of implementing Community Service is carried out interactively with a video conversion application ZOOM on 25 youth cadets in the village of Mojogede, Balongpanggang Gresik on June 14, 2020. Before starting the event the participants were given a face shield that must be used during the event as an effort to implement health protocols. Furthermore, pre-test is given first, then material exposure is carried out and continued filling in post-test with the same problem. Based on the results of the pre-test and post-test obtained an increase in public knowledge which was $79.09 \%$ to $89.23 \%$.
\end{abstract}

Keywords: Covid-19; Sars-CoV-2; immunity

Abtrak: Coronavirus Disease 2019 (Covid-19) adalah penyakit jenis baru yang belum pernah diidentifikasi sebelumnya pada manusia. Virus penyebab Covid-19 ini dinamakan Sars-CoV-2. Penelitian ini dilakukan untuk memberikan edukasi terhadap masyarakat tentang pemanfaatan minuman fungsional kombinasi jahe dan serai untuk meningkatkan imunitas. Metode pelaksanaan Pengabdian Kepada Masyarakat dilakukan melalui penyuluhan interaktif dengan video converence aplikasi ZOOM pada 25 karang taruna desa Mojogede, Balongpanggang Gresik pada tanggal 14 Juni 2020. Sebelum dimulai acara para peserta diberikan face shield yang harus digunakan selama acara berlangsung sebagai upaya penerapan protocol kesehatan. Selanjutnya diberikan pre-test terlebih dahulu, kemudian dilakukan pemaparan materi dan dilanjutkan pengisian post-test dengan soal yang sama. Berdasarkan hasil pre-test dan post-test didapatkan peningkatan pengetahuan masyarakat yang sebelumnya yaitu $79,09 \%$ menjadi $89,23 \%$.

Kata Kunci: Covid-19; Sars-Cov-2; imunitas

\section{PENDAHULUAN}

Coronavirus merupakan keluarga besar virus yang menyebabkan penyakit mulai dari gejala ringan sampai berat. Coronavirus diketahui dapat menyebabkan penyakit yang dapat menimbulkan gejala berat seperti Middle East Respiratory Syndrome (MERS) dan Severe Acute Respiratory Syndrome (SARS). Coronavirus Disease 2019 (Covid-19) adalah penyakit jenis baru yang belum 
pernah diidentifikasi sebelumnya pada manusia. Virus penyebab Covid-19 ini dinamakan Sars-CoV-2. Virus corona merupakan zoonosis, yang artinya ditularkan antara hewan dan manusia. Sebuah penelitian menyebutkan bahwa SARS ditransmisikan dari kucing luwak (civet cats) ke manusia dan MERS dari unta ke manusia (Direktorat Jenderal Pencegahan dan Pengendalian Penyakit, 2020). Indonesia merupakan Negara yang kaya akan rempah-rempah. Rempah-rempah merupakan bahan tambahan bagi masyarakat Indonesia dan banyak digunakan sebagai bumbu dapur dalam masakan tradisional, seperti jahe dan serai. Selain sebagai bumbu dapur, jahe dan serai dapat digunakan sebagai bahan utama dalam pembuatan minuman sehat yang disebut sebagai minuman fungsional. Minuman fungsional merupakan minuman sehat yang mengandung unsur-unsur zat gizi atau non zat gizi dan dapat memberikan manfaat pada tubuh ketika dikonsumsi (Winarti, 2010). Kegiatan pengabdian masyarakat ini dilakukan di Kecamatan Balongpanggang.

Balongpanggang adalah salah satu dari 18 kecamatan yang ada di Kabupaten Gresik. Balongpanggang memiliki 25 Desa, salah satunya adalah Desa Mojogede. Desa Mojogede merupakan salah satu desa dari Kecamatan Balongpanggang yang terdiri dari 3 dusun, diantaranya dusun Mojogede, dusun Karangwungu dan dusun Mojolebak dengan jumlah penduduk 1900 Jiwa atau 620 KK. Terdapat banyak kegiatan Organisasi Masyarakat (Ormas) di Desa Mojogede. seperti Remaja Masjid, Karang Taruna, Jamiyah Yasin, Tahlil, PKK Dharma wanita, Posyandu dan kelompok Arisan. Kegiatan organisasi masyarakat tersebut merupakan aset desa yang bermanfaat untuk dijadikan media penyampaian informasi dalam setiap kegiatan.

Salah satu daya tarik yang berpotensi untuk dikembangkan di Kecamatan Balongpanggang adalah Desa Mojogede. Desa Mojogede merupakan desa yang memiliki kekayaan khas tersendiri sebagai potensi pengembangan desa, yaitu tanaman serai. Serai umumnya tumbuh sebagai tanaman liar di tepi jalan atau kebun, tetapi dapat ditanam dalam berbagai kondisi di daerah tropis yang lembab, cukup sinar matahari dan bercurah hujan relatif tinggi (Agusta, 2002).

Tanaman sereh merupakan tumbuhan herba menahun tergolong dalam jenis rumput rumputan dan merupakan jenis tanaman dengan tinggi mencapai 50-100 cm. Tanaman sereh (Cymbopogon citrates) mempunyai bagian bagian antara lain akar, batang dan daun. Akar tanaman sereh biasanya dimanfaatkan sebagai obat tradisonal dan batang serai mengandung minyak atsiri yang dimanfaatkan sebagai bumbu dapur dengan aroma (Sastrohamidjojo, 1996). Berdasarkan penelitian yang dilakukan oleh Yuliningtyas dkk (2019) menyatakan bahwa minuman serai dan jahe mengandung beberapa senyawa aktif, yaitu alkaloid, flavonoid dan saponin.

Kegiatan ini mengacu pada kondisi pandemic Covid-19 di Indonesia yang terjadi saat ini. Oleh karena itu, perlu dilakukan kegiatan pengabdian kepada masyarakat yang bertujuan untuk mengedukasi masyarakat tentang pemanfaatan minuman fungsional kombinasi jahe dan serai untuk meningkatkan imunitas tubuh, apalagi saat dalam pandemic Covid-19.

\section{METODE}

Kegiatan Pengabdian Kepada Masyarakat ini dilaksanakan pada tanggal 13 Juni 2020 di Dusun Karangwungu Desa Mojogede Kecamatan Balongpanggang Kabupaten Gresik. Metode yang digunakan pada pengabdian kepada masyarakat ini adalah metode sosialisasi yang dilakukan secara virtual dengan menggunakan aplikasi ZOOM. Metode ini diterapkan untuk memberikan informasi terkait cara meningkatkan imunitas dengan minuman fungsional. Hal ini sangat penting untuk membentuk masyarakat yang lebih sehat dengan meningkatkan system imun tubuh disaat pandemic 
Covid-19 ini. Khalayak sasaran pengabdian kepada masyarakat ini adalah masyarakat Dusun Karangwungu Desa Mojogede Kecamatan Balongpanggang Kabupaten Gresik dengan jumlah peserta sebanyak 25 orang yang terdiri karang taruna, perangkat dusun dan bidan.

Kegiatan pengabdian kepada masyarakat dilakukan melalui beberapa tahapan, yaitu:

1) Penerapan protocol kesehatan sesuai anjuran pemerintah,

2) Pembagian kuesioner pre-test untuk mengetahui pemahaman peserta terkait materi imunitas dan minuman fungsioanl sebelum mendapatkan penyuluhan.

3) Penyuluhan oleh pemateri menggunakan media ppt dan alat bantu berupa face shield sebagai media penyuluhan dalam memahami materi dengan mudah. Saat penyuluhan berlangsung, peserta dapat bertanya tentang materi yang telah disampaikan.

4) Pembagian kuesioner post test untuk mengetahui pemahaman peserta setelah diberikan penyuluhan,

Untuk mengetahui keberhasilan kegiatan pengabdian kepada masyarakat ini, dilakukan dengan melihat keterlibatan dan antusias peserta. Keterlibatan peserta dapat dilihat dari absen peserta dan antusiame peserta ketika bertanya tentang materi yang telah disampaikan. Selain itu, juga digunakan instrument angket/kuesioner untuk mengumpulkan data mengenai pemahaman peserta sebelum dan setelah diberikan penyuluhan.

\section{HASIL DAN PEMBAHASAN}

Kegiatan penyuluhan minuman fungsional untuk meningkatkan system imun tubuh di Kecamatan BalongpanggangGresik ini merupakan suatu program kegiatan Program Studi Farmasi dalam rangka Pengabdian kepada Masyarakat (PKM) Internal Universitas Muhammadiyah Gresik. Kegiatan PKM ini menggunakan tema pemanfaatan herbal sebagai minuman fungsional untuk meningkatkan system imun tubuh. Penggunaan tema herbal ini merupakan penciri khas Program Studi DIII Farmasi Fakultas Kesehatan Universitas Muhammadiyah Gresik. Kegiatan PKM ini bertujuan untuk mengedukasi masyarakat tentang pentingnya pemahaman tentang pemanfaatan tanaman herbal sebagai minuman fungsional dengan harapan dapat membantu masyarakat setempat dalam menjaga kesehatan di masa pandemic Covid-19.

Kegiatan PKM ini dimulai dengan pembukaan dan sambutan oleh Ketua Panitia yang menjelaskan mengenai tujuan, manfaat dan rangkaian kegiatan penyuluhan minuman fungsional untuk meningkatkan system imun tubuh. Setelah itu, dilanjutkan sambutan oleh Kepala Dusun Karangwungu setempat yang menjelaskan tentang kegiatan penyuluhan ini beserta manfaatnya. Sebelum penyuluhan materi dimulai, tahapan pertama kegiatan ini adalah dilakukan pembagian face shield terlebih dahulu oleh panitia kepada seluruh peserta, yang mana harus digunakan selama kegiatan. Pembagian face shield ini merupakan salah satu upaya bentuk penerapan protocol kesehatan selama kegiatan PKM berlangsung. Face shield digunakan untuk melindungi wajah (mata, hidung dan mulut) dari paparan percikan droplet atau tangan yang terkontaminasi bakteri atau virus. Selain itu, face shieldini juga dapat digunakan setiap hari oleh peserta saat berada di luar rumah karena bisa dibersihakn dengan menggunakan desinfektan. 


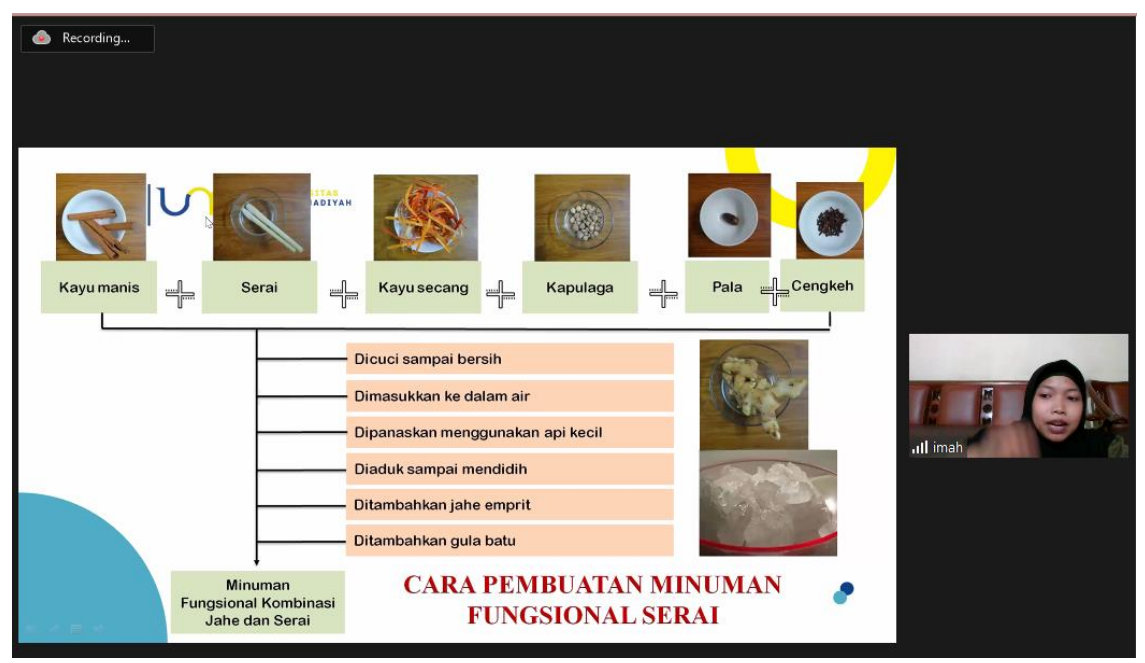

Gambar 1. Pemateri menjelaskan tentang cara pembuatan minuman fungsional

Tahapan kedua adalah pemateri membagikan kuisioner (pre-test) yang harus diisi oleh peserta untuk mengetahui tingkat pengetahuan peserta terkait pemanfaatan herbal sebagai minuman fungsional. Berdasarkan hasil pre-test tersebut, menunjukkan bahwa pemahaman peserta terkait materi kegiatan pengabdian kepada masyarakat ini sebesar 79,09\%. Kemudian dilanjutkan tahapan ke 3 yaitu penjelasan tentang imunitas beserta cara meningkatkannya yang bertujuan untuk memberikan pengetahuan kepada masyarakat tentang pentingnya menjaga system imun tubuh untuk mencegah terjadinya pemaparan benda asing yang masuk ke dalam tubuh, seperti virus dan bakteri (Sastrohamidjojo, 1996). Upaya untuk meningkatkan system imun tubuh harus dilakukan dengan memperhatikan beberapa hal yaitu mengonsumsi makanan bergizi, berolahraga secara rutin, mengelola stress dengan baik, beristirahat yang cukup serta mengonsumsi suplemen penunjang daya tahan tubuh. Suplemen yang dikonsumsi untuk meningkatkan system imun tubuh adalah yang mengandung vitamin dan mineral, seperti vitamin $\mathrm{C}$, vitamin $\mathrm{A}$, fosfor, kalium dan lain sebagainya. Beberapa vitamin dan mineral tersebut dapat ditemukan dalam kandungan tanaman herbal, seperti jahe dan serai.

Selanjutnya, dilakukan tahapan ke 4 yaitu penyuluhan tentang pemanfaatan herbal untuk pembuatan minuman fungsional, yang mana merupakan berbahan alami atau berasal dari rempahrempah dan memiliki banyak khasiat bagi kesehatan dan sebagai peghilang rasa haus. Salah satu bahan alami atau rempah-rempah yang digunakan untuk pembuatan minuman fungsional adalah jahe, serai, kunyit dan lain sebagainya. Minuman fungsional yang diproduksi pada program pengabdian kepada masyarakat ini adalah kombinasi antara jahe dan serai. Minuman fungsional ini dimanfaatkan untuk menjaga system imun tubuh saat menjalankan masa transisi new normal saat ini. Bahan-bahan yang digunakan dalam pembuatan minuman fungsional ini, antara lain serai, jahe emprit, kayu manis, kapulaga, pala, cengkeh, gula batu dan air. Cara pembuatan minuman fungsional kombinasi jahe dan serai yaitu a) semua bahan dicuci sampai bersih dan dimasukkan (kecuali jahe emprit) ke dalam wadah yang berisi air, b) lalu, dipanaskan dengan menggunakan api kecil dan diaduk sampai mendidih, c) ditambahkan jahe emprit yang digeprek dan gula batu, d) diaduk kembali serta dibiarkan sampai menjadi hangat dan siap untuk dikonsumsi. 


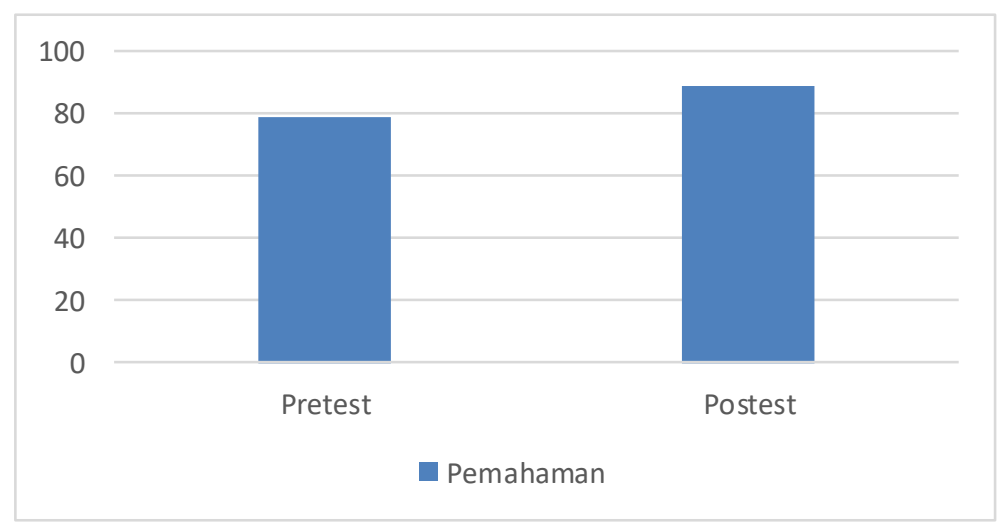

Gambar 2. Grafik hubungan antara pemahaman peserta pengabdian kepada masyarakat saat melakukan pre-test dan post-test

Tahapan ke 5 dilanjutkan dengan sesi tanya jawab untuk mengetahui dan memahami lebih lanjut tentang minuman fungsional untuk meningkatakan system imun tubuh. Pada sesi tanya jawab, respon masyarakat sangat baik yang terlihat dari banyaknya pertanyaan yang disampaikan kepada pemateri. Hal tersebut menunjukkan hasil refleksi/bentuk keingintahuan masyarakat terhadap materi tersebut yang dapat menimbulkan dampak positif bagi masyarakat. Kemudian dilanjutkan dengan pengisian kuisioner (post-test) untuk mengetahui tingkat pengetahuan peserta setelah mendapatkan materi penyuluhan. Berdasarkan hasil post-test menunjukkan bahwa peserta lebih mengetahui tentang materi yang disampaikan, yaitu pemanfaatan minuman fungsional untuk meningkatakan imunitas tubuh. Hal tersebut diketahui karena terjadinya peningkatan persentase pemahaman masyarakat setelah dilakukan penyuluhan, yaitu sebesar $89,23 \%$. Hal tersebut menunjukkan bahwa kegiatan penyuluhan ini meningkatkan pengetahuan masyarakat terkait pemanfaatan herbal untuk meningkatkan system imun tubuh di masa pandemic Covid-19 saat ini.

\section{KESIMPULAN DAN SARAN}

\section{Kesimpulan}

Masyarakat Dusun Karangwungu Desa Mojogede Kecamatan Balongpanggang Kabupaten Gresik memahami tentang pemanfaatan minuman fungsional kombinasi jahe dan serai untuk meningkatkan imunitas tubuh.

\section{Saran}

Berdasarkan animo karang taruna desa Mojogede maka perlu diadakannya pengabdian kepada masyarakat dalam bentuk pelatihan pembuatan minuman fungsional dengan kombinasi jahe dan serai, sehingga mampu digunakan untuk kebutuhan sendiri ataupun dijual.

\section{Ucapan Terima Kasih}

Ucapan terima kasih kepada Lembaga Penelitian dan Pengabdian Masyarakat Universitas Muhammadiyah Gresik selaku penyandang dana pada kegiatan pengabdian masyarakat internal. 


\section{DAFTAR PUSTAKA}

Agusta, A. 2002. Aromaterapi Cara Sehat dengan Wewangian Alami. Jakarta: Penebar Swadaya.

Direktorat Jenderal Pencegahan dan Pengendalian Penyakit. 2020. Pedoman Pencegahan dan Pengendalian Coronavirus Disease (Covid-19). Jakarta: Kementerian Kesehatan Republik Indonesia.

Sastrohamidjojo, H. 1996. Sintesis Bahan Alam. Cetakan ke-1. Liberty: Yogyakarta.

Winarti, S. 2010. Makanan Fungsional. Surabaya: Graha Ilmu.

Yuliningtyas, A.W., Hari S. dan Ahmad S. 2019. Uji Kandungan Senyawa Aktif Minuman Jahe Sereh (Zingiber officinale dan Cymbopogon citrates). Biosaintropis (Bioscience-Tropic). Vol.4, No.2, Hlm: 1-6. ISSN 2460-9455(e) - 2338-2805(p). 